\title{
State of practice in accessible instructional material policy in public post-secondary settings
}

\author{
Veronica McGowan, D.Ed. \\ Southwest Oklahoma State University
}

\begin{abstract}
For many students, easy access to instructional materials is an expectation of course enrollment. However, for students with disabilities, obtaining instructional materials may involve hurdles such as transcription, captioning, and requesting a braille or large-print version. In order to explore themes related to accessibility and services for students with disabilities, the goal of this study was to examine the similarities and differences between publicly communicated policies related to accessible instructional materials in public post-secondary educational settings. To that end, this study consists of website-provided accessible instructional materials policy of 60 higher educational institutions, representing five American geographic areas and four institutional types in order to discover common themes in the presentation of findings. While high resource institutions presented the largest breadth of findings, duplication of purposes meant that some institutions with lower resource levels presented materials in a more comprehensive grouping manner. In addition, evidence exists that institutions are presenting an incomplete picture of accessibility requirements and despite the prevalence of resources, service regarding accessible instructional materials is uneven across institutional types and locations.
\end{abstract}

Keywords: Instructional Materials, Accessibility, Campus Policy, Accessible Instruction

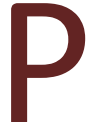

roviding accessible instructional materials in academic settings is important for promoting equality and complying with federal and state laws. So powerful has been accessibility-related legislative and lobbying activity, that the federal Department of Education has created an Advisory Commission on Accessible Instructional Materials in Postsecondary Education for Students with Disabilities (ed.gov/about/bdscomm/list/aim) in order to forward initiatives and progress. However, at the state level, policies ensuring equitable access to library and instructional resources have been slow to develop with some states adopting policies only in recent years, and as of this writing, 28 states do not have a policy in the overall category of instructional materials adoption (State Educational Technology Directors Association, 2018). In addition, there is evidence that reaction to, and implementation of, state policies is inconsistent or uncoordinated in the filter down from systems to institutions (Adams, Halaychik, \& Mezick, 2018) and perhaps vulnerable to compliance challenges. Even worse, policies trickling down to the institutional level may not reflect best practices despite widespread attention to accessibility concerns in the field of education (O'Connor, 2014; Flaherty \& Roussy, 2014). Ideally, institutions might invest in a Center for Accessible Materials or a library accessibility specialist; however, recent field discussion indicates that role is quite new and often not dedicated to accessibility support on a full-time basis (Rosen, 2018). Worse, there is widespread acknowledgment that the availability of accessible instructional materials exists on a continuum in high-resource countries (Blummer \& Kenton, 2017; George et al., 2014) and other international settings (Mishra, Pattanaik, \& Mahapatra, 2017; Phukubje \& Ngoepe, 2016). Proactive field discussion from publishing interests acknowledge that complicacy is related to a lack of

MCGOWAN / DOI: 10.5929/2019.1.14.2 
legal mandates requiring publishers to make materials accessible (Axelrod, 2017), as well as a slow transition to accessible standards, such as a replacement of PDF by EPUB as a standard in accessible documentation (Conrad \& Kasdorf, 2018).

Despite trends in accessibility services to offer a proactive educational setting, services in post-secondary institutions still center on a reactive model (Slater et al., 2015) with wait-times to receive accessible materials commonly exceeding field standards of two days by a significant amount (Brand, Valent, \& Danielson, 2013). Students in some disability categories are less likely to enroll in higher educational programs (Grigal, Hart, \& Migliore, 2011; Wei et al, 2013), and have poorer retention (King, 2014) and time to degree rates (Knight, Wessel, \& Markle, 2016), although mitigations such as transition planning and goal-setting are effective (Wei, Peng, $\&$ Chou, 2015). In addition, field literature points to a significant lack of training for preservice teachers (Vitelli, 2015) and expertise in faculty regarding accessibility issues and accommodations (Levey, 2018; Gallego \& Busch, 2015), although educational interventions are highly effective for promoting accessibility issues at design levels (Larkin, Dell, \& Hitch, 2016). With an uptick in the number of students classified with a learning disability (Cortiella \& Horowitz, 2014), it has never been more important to address current shortfalls in accessible instruction. Course support ideals may be closer than we think as emerging field literature is increasingly positioning accessible course resources into best practice models for effective learning (Cifuentes et al., 2016; Small, Myhill, \& Herring-Harrington, 2015).

\section{Literature Review}

Since access to education is considered one of the primary ways to access high-paying employment and influence quality of life, several federal laws address accessibility, with one of the most prominent being the American with Disabilities Act (ADA) along with its titled concerns related to places of public accommodation (Title III, 42 U.S.C. §§ 12181-12189) and telecommunications (Title IV, 47U.S.C. § 225). In addition, section 504 (29 U.S.C. $\S 701$ ) of the Rehabilitation Act of 1973 and section 255 of the Telecommunications Act (FCC, 2013) have provisions that directly impact higher education.

\section{Policy and Legal Requirements}

In their literature review, Yang and Chen (2015) noted that state laws on Web accessibility fall on a continuum of variation ranging from executive policy to legislation with guidance offered by field standards. The literature review of this current study updates Yang and Chen's Table 1 Listing of State Web Accessibility Policy to note that only the states of Nevada and Wyoming still do not offer an accessibility policy as of this writing; however, Nevada offers an extensive website addressing their compliance with federal accessibility law. Three other states (Delaware, North Carolina, and Oregon) offer an accessibility statement and either offer information about their status of compliance issues or discuss how their state websites have implemented accessibility mitigation. Enforcement of the ADA falls to the Department of Justice's Civil Rights Division and despite these robust laws, the Information Technology Systems and Services department at the University of Minnesota at Duluth has compiled an up-to-date list of 37 complaints related to higher education accessibility that represent a range of institutional types (http://www.d.umn.edu/ Icarlson/atteam/lawsuits.html). Field organizations would seem to concur with observed lapses due to significant investment in instructional material accessibility standards development (National Center on Accessible Educational Materials, 2004).

For instructional materials provided in a closed environment to a known audience, materials must be compliant with federal and state laws, and material must be accessible to a student who presents with a

MCGOWAN / DOI: 10.5929/2019.1.14.2 
qualifying disability. For public materials, the institution opens itself to liability as not being accessible if materials are not compliant.

\section{Effectiveness of Accessible Instructional Materials}

Increasingly, higher education is adopting a universal instructional design principle as a framework for instructional design, learning platforms, and communication mediums as research in indicating that the employment of universal design is improving student learning (Black, Weinberg, \& Brodwin, 2015). The use of Universal Design principles and technology interventions in accessible instructional materials have been shown to be effective for reducing preparation and student wait times (Kaufmann, Perez, \& Bryant, 2018) and increasing student satisfaction with instructors (Basham, Lowrey, \& deNoyelles, 2010). Yet, despite a healthy set of Universal Design principles, guidelines, and related literature, Alexrod (2017) noted that the state of accessible materials has been little changed since a 2011 report to Congress offering progress recommendations, even though calls to scale up Universal Design adoption in the field are prevalent (Izzo \& Bauer, 2015; Moore et al., 2017). Faculty knowledge of accessibility information is still a barrier to effective instruction with deficits noted in the number of institution-based experts (Shinohara et al, 2018), methods of improving the accessibility of materials (Gladhart, 2010), as well as legal mandates, mitigating instructional barriers, and accessible material formats (Lombardi \& Murray, 2011).

Given that most individuals access instructional materials through some type of Web presence or learning management system, and that high interaction with provided online components has been linked to higher achievement (Akhtar, Warburton, \& Wu, 2017; Wei, Peng, \& Chou, 2015), environment accessibility is a relevant topic. While most higher education institutions have had a website presence for nearly thirty years with the structure supporting Web communication expanding to embrace technical and promotional aspects, the quality of Web content (Margolin, Shazia, \& Rosenbaum, 2014) and accessibility and usability of website versions (Azadbakht, Blair, \& Jones, 2017; Ringlaben, Bray, \& Packard, 2014) has not consistently met demand with Massengale and Vasquez (2016) finding that five (5) types of challenges involving formatting, resource links, content presentation, incompatibility, and scripting issues consistently impact the accessibility of online courses. In fact, a comparable analysis of university websites by Alahmadi and Drew (2015) revealed that accessibility issues are requiring increased resolution time and resources, likely linked to the increasing complexity of content delivered in various formats. In reviewing the literature, while usability testing of websites is a common theme, linkages to accessibility is less common, with field discussion indicating that low accessibility ratings for higher education websites in American and international settings are widespread. Some discussion elevates this concern to indicate a disregard for accessibility guidelines and legislation (Acosta-Vargas, Acosta, \& Luján 2018; Akram \& Sulaiman, 2017). Moreover, usability testing tends to focus on navigational features, such menus and links, and with usability concerning content items typically restricted to discussion related to format robustness, such as a presentation of a PDF, and less on testing for the presence of universal design principles.

In addition, recent research has revealed low accessibility compliance with popular Learning Management Systems (LMS) for various populations (Chen et al., 2015; Pirani \& Sasikumar, 2014) despite prominent field recommendations for LMS to include accessibility and Universal Design as one of five core functionalities (Brown, Dehoney, \& Millichap, 2015). Kent (2015) would seem to agree, noting the low field organization certification rate of learning management systems at a top-tiered level, which indicates the highest rates of compliance.

MCGOWAN / DOI: 10.5929/2019.1.14.2 
Dong and Lucas (2016) found that identified students are not requesting accommodations in a number compatible with their representation, despite the proven effectiveness of the accommodation. Seale et al., (2015) would seem to agree with findings from their study, indicating that students are not exploiting resources to their full extent, with resources not appropriately or effectively dispersed or managed for the population. While accuracy is continuing to improve for technologies related to accessibility (Chern et al., 2017), such as transcription or captioning technologies, known technology limitations continue to challenge stakeholders wishing to easily incorporate accessible mechanisms into material provision (Dunnam, 2016; Zekveld et al, 2009). DeLancey (2015) questions the trustworthiness of commercial solutions with finding that a significant amount of vendor-supplied materials purported to be accessible when they were not compliant. Research literature notes a dearth of studies concerning the effectiveness of various institutional support services in general (McGuire, 2014), as well as for various populations, such as the hearing-impaired population (Noble, 2010).

Based upon this literature review, preparation for data collection and analysis involved an awareness that the policies presented may be reflective of advocacy initiatives and motivations of local settings. For example, studied institutions with prominent special education academic programs might more closely reflect best practices as their faculty experts organically engage with campus stakeholders.

\section{Methodology}

As consistent with research investigations of website provision of policy (Grana \& Ling, 2014; Rains \& Bosch, 2009), a content analysis methodology quantified and analyzed the presence of findings in context with field guidelines regarding accessibility issues. The population of interest was accessible material policies reflecting the continuum of public American college and university settings. Therefore, a strategic sample of 60 postsecondary institutional websites, representing five American geographic areas and four institutional types: very high research activity, master's level, state colleges or bachelor's level, and community colleges were studied to discover common themes in the presentation of findings. The study literature review informed the creation of a coding instrument with identified themes and policy specifics. The coding instrument developed with both a priori and empirical observations, with both members of the research team offering refinement to the developing instrument during the pilot study resulting in the final instrument used in the research study (Neuendorf, 2016). The pilot study consisted of a convenience sample of one state's continuum of public institutions and immediately proceeded the research study.

Searched Websites deployed a categorical search of likely subunit sites, including Disabilities Services, Center for Teaching Excellence, Instructional Technology, and Distance Learning, as well as a Search Term search. Search terms included: accessibility of instructional materials, accessible material policy, and captioning. Since disability services is typically a function of a larger student services unit, searching focused on faculty-facing materials. Searching continued until researchers were confident that all avenues were exhausted. With only three institutions (5\%) not presenting any findings, researchers were confident that their search method was robust, given that a 2013 study found that only $8.4 \%$ of postsecondary institutions had Web or technology accessibility policies (Thompson et al., 2013). Findings were recorded in the coding instrument by two independent passes of members of a research team that consisted of a primary investigator and trained assistant. Therefore, with 215 investigations, intercoder reliability was measured at .83 according to guidelines by Lombard, Snyder-Duch, \& Bracken (2002). When findings resulted in a dispute, a consensus round was deployed to determine finding prominence. Findings were judged as relevant if provided in the policy itself or immediately adjunct as part of a contained sponsor Website or other designated Website. Materials that addressed accessibility of web promotional materials were disregarded unless there was evidence that the provision served multiple

MCGOWAN / DOI: 10.5929/2019.1.14.2 
purposes - a common tactic at smaller institutions. Finally, in order to illustrate a commitment to services, one service related to accessible instructional materials (in this case video captioning) served in the investigation.

\section{Results}

In the below tables, when multiple findings occurred, the top two most significant findings were reported.

Table 1

Incidence rates of Accessible Instructional Material policy elements for entire sample

\begin{tabular}{|l|l|}
\hline & \multicolumn{1}{|c|}{ Sample incidence rate } \\
\hline Policy purpose & $51.6 \%$ accessibility \\
& $28.3 \%$ accommodation \\
\hline Legal Mandate & $48.3 \%$ federal only \\
& $21.6 \%$ federal and state \\
& $21.6 \%$ no mandate listed \\
\hline Extent that policy is enforced & $20 \%$ accommodation \\
\hline Definitions provided & $15 \%$ recommended \\
\hline Content development guide & 139 \\
\hline Resources\Accessibility Evaluation Tool & $60 \%$ \\
\hline Captioning\Transcription Service & $58.3 \%$ \\
\hline Responsibilities stated & $48.3 \% / 9 \%$ \\
\hline Policy Exceptions & $46.6 \%$ \\
\hline Standards provision\reference & $28.3 \%$ \\
\hline Non-discrimination\equal opportunity statement & $28.3 \%$ \\
\hline Provision of syllabus statement $\backslash$ template & $23.6 \%$ \\
\hline Purchasing accessible materials & $23.3 \%$ \\
\hline Grievance process & $20 \%$ \\
\hline Confidentially & $18.3 \%$ \\
\hline Priority algorithm & $13.3 \%$ \\
\hline Temporary Disabilities & $10 \%$ \\
\hline Implementation Plan & $8.3 \%$ \\
\hline Parent\family resources & $8.3 \%$ \\
\hline & \\
\hline
\end{tabular}


Table 2

Incidence rates of Accessible Instructional Material policy elements by Institutional Type

\begin{tabular}{|c|c|c|c|c|}
\hline & Very High Research & Master's-level & State Colleges & $\begin{array}{c}\text { Community } \\
\text { Colleges }\end{array}$ \\
\hline Policy purpose & $\begin{array}{l}60 \% \text { accessibility } \\
26.6 \% \\
\text { accommodation }\end{array}$ & $\begin{array}{l}53.3 \% \text { accessibility } \\
26.6 \% \\
\text { accommodation }\end{array}$ & $\begin{array}{l}33.3 \% \text { accessibility } \\
40 \% \text { accommodation }\end{array}$ & $\begin{array}{l}46.6 \% \\
\text { accessibility } \\
26.6 \% \\
\text { accommodation }\end{array}$ \\
\hline Legal Mandate & $\begin{array}{l}40 \% \text { federal only } \\
33.3 \% \text { federal and } \\
\text { state }\end{array}$ & $\begin{array}{l}53.3 \% \text { federal only } \\
26.6 \% \text { no mandate } \\
\text { listed }\end{array}$ & $\begin{array}{l}46.6 \% \text { federal only } \\
26.6 \% \text { federal and } \\
\text { state }\end{array}$ & $\begin{array}{l}60 \% \text { federal only } \\
20 \% \text { federal and } \\
\text { state }\end{array}$ \\
\hline $\begin{array}{l}\text { Extent that policy is } \\
\text { enforced }\end{array}$ & $23.3 \%$ indicated & $30 \%$ indicated & $23.3 \%$ indicated & $23.3 \%$ indicated \\
\hline Definitions provided & 47 & 58 & 25 & 9 \\
\hline $\begin{array}{l}\text { Content development } \\
\text { guide }\end{array}$ & $36 \%$ & $27.7 \%$ & $16.6 \%$ & $19.4 \%$ \\
\hline $\begin{array}{l}\text { Resources } \backslash \\
\text { Accessibility } \\
\text { Evaluation Tool } \\
\end{array}$ & $34 \%$ & $22.8 \%$ & $23.2 \%$ & $20 \%$ \\
\hline $\begin{array}{l}\text { Captioning } \\
\text { Transcription Service }\end{array}$ & $34.4 \%$ & $31 \%$ & $21 \%$ & $13.7 \%$ \\
\hline Responsibilities stated & $17.8 \%$ & $28.5 \%$ & $14.3 \%$ & $21.4 \%$ \\
\hline Policy Exceptions & $29.4 \%$ & $23.5 \%$ & $23.5 \%$ & $23.5 \%$ \\
\hline $\begin{array}{l}\text { Standards } \\
\text { provision\reference }\end{array}$ & $41 . \%$ & $23.5 \%$ & $11.7 \%$ & $23.5 \%$ \\
\hline $\begin{array}{l}\text { Non- } \\
\text { discrimination \equal } \\
\text { opportunity statement }\end{array}$ & $43.7 \%$ & $23.5 \%$ & $20.2 \%$ & $12.5 \%$ \\
\hline $\begin{array}{l}\text { Provision of syllabus } \\
\text { statement \template }\end{array}$ & $35 \%$ & $28.5 \%$ & $35 \%$ & $7 \%$ \\
\hline $\begin{array}{l}\text { Purchasing accessible } \\
\text { materials }\end{array}$ & $50 \%$ & $21.4 \%$ & $7 \%$ & $21.4 \%$ \\
\hline Grievance process & $0 \%$ & $18 \%$ & $50 \%$ & $32 \%$ \\
\hline Confidentially & $36.3 \%$ & $36.3 \%$ & $9 \%$ & $18 \%$ \\
\hline Priority algorithm & $62.5 \%$ & $25 \%$ & $12.5 \%$ & $0 \%$ \\
\hline Implementation Plan & $40 \%$ & $20 \%$ & $0 \%$ & $40 \%$ \\
\hline $\begin{array}{l}\text { Parent \family } \\
\text { resources }\end{array}$ & $40 \%$ & $20 \%$ & $40 \%$ & $0 \%$ \\
\hline
\end{tabular}


Table 3

Meta information

\begin{tabular}{|l|l|}
\hline Policy Sponsor & Disability Services 35\% \\
& $18 \%$ Accessible Materials or Technology Committee \\
& $12 \%$ unclear \\
& $10 \%$ Student Services \\
& $7 \%$ Information Technology Services \\
& $7 \%$ Other \\
& $5 \%$ Center for Teaching Excellence \\
& $5 \%$ no policy provided \\
\hline Policy Name & Variation of Accessibility policy 35\% \\
& Variation of environment policy 20\% \\
& Variation of accommodation policy $20 \%$ \\
& Variation of faculty instructional name $15 \%$ \\
\hline Course & $3 \%$ \\
\hline
\end{tabular}

\section{Discussion}

In this study, typically two content areas revealed Web accessibility policy findings: web communication and marketing for promotional website purposes, and, the focus of this study, the accessibility of instructional materials provided through some Web platform, such as a Learning Management System. Policies of the latter category are typically found under a provost-controlled area, such as Disabilities Services or an umbrella organization of Student Services, the institutional center for teaching excellence, or instructional technology support unit. However, $27 \%$ of institutions either did not identify a sponsor or made sponsorship unclear, provided sponsorship under an unaffiliated unit such as Public Relations, or did not provide a policy.

While the findings of this study regarding policy purpose recorded the exact words, it is important to recognize distinctions, especially given that only $35 \%$ of eligible higher education students seek accommodations (Newman et al., 2011). Accessibility refers to the provision of materials, such as video captions, for all students so that others besides those without an identifiable disability might benefit. Accommodation refers to provision for a specific, identified student. This study's findings that the provision of a purpose and legal mandate was important to user perception is was seemingly confirmed by McClellan et al. (2016), who noted the importance of fulfilling end-user expectations.

While some results, including higher aggregate category averages, indicate that well-resourced institutions have a more comprehensive Accessible Instructional Materials program with dedicated committee sponsorship and a greater number of finding appearances, this may not reflect the true state of affairs. In some cases, policy materials disseminated broadly through the organizational structure with policy at some smaller institutions are doing double duty to reflect web promotional materials. In the opposite extreme, larger institutions have a repetitive structure geared to audiences. Specific resource support was a popular theme of this study. A positive surprising finding was the large number of institutions that have committed to accessibility by providing links to external resources and \or some type of evaluation tool or guide so that faculty participants can foster a more accessible environment. A significant number of institutions offer some form of video captioning or transcription service, a practice

MCGOWAN / DOI: 10.5929/2019.1.14.2 
well-aligned with field recommendations due to their impact on comprehension of video content in populations of deaf students (Tyler et al., 2009).

The literature review prepared us for findings of significant knowledge constraints among faculty, so this study's findings that a significant number of institutions proactively provide a statement or template for faculty to incorporate into a syllabus is not surprising. The specific address of purchasing in policy materials was unexpected, with expectations being that purchasing regulations are hosted in a Business Affairs section or not provided publicly. Clearly, wider provisions in an accessibility policy benefit a wide swath of stakeholders, some of whom may be invested in decision-making on behalf of the institution. Given that several policies explicitly note that accommodation occurs to the extent feasible, it is surprising that an explicit address of a grievance process occurs in low numbers; the federal Office of Civil Rights (OCR) encourages the adoption and publication of multiple internal grievance procedures (OCR, n.d.). Several findings of low significance appear to be used by policymakers to raise awareness of a particular issue. For example, findings of policy address of confidentially are low when in fact, given the narrow scope of this policy, the numbers are believed to be high with the majority of institutions offering a general statement of confidentially of student data in a more prominent, general area with applicability to all students. As indicated in the methodology section, findings were only listed if found in the policy or on a closely related page or area; other low findings that potentially raise awareness include the provision of a non-discrimination or equal opportunity statement.

While a relatively low number of institutions publish their algorithms for determining service priorities, a surprising finding is that those that did, a large number consisted of high-resource institutions, although it may be that those institutions are fostering transparency and likely that low-resource institutions have an unpublished internal procedure. Field literature seems to confirm study supposition that an informal procedure exists for prioritizing disability service requests (Carey, 2015). Given the significant workload required to convert or otherwise produce alternative materials (Oku, Matsubara, \& Booka, 2015), it is surprising that this study does not support that a large percentage of institutions are publicly communicating priority systems for handling service requests, although institutions may have reservations about making that information transparent for fear of discouraging requests. A surprising low finding was that few institutions addressed services to students with temporary disabilities; in addition, $5 \%$ of schools had policies that would seem to prevent students with temporary disabilities for applying for services after the semester had begun. Themes in the literature review concerning under compliance prepared researchers for findings related to broadcasting of an implementation plan, perhaps provided to show good faith efforts in complying with accessibility law.

Concerning the study variable meant to illustrate practice, when it comes to providing video captioning, universities are presenting a spectrum on the clarity of legal advice with some institutions stating that all material must be captioned while others note that closed settings with known audiences do not need to be captioned. Captioning is acknowledged to be "a best practice" for accessibility for all populations, including ESL, low hearing, etc (Mayes, 2018). With a significant number of institutions offering a service of evaluating materials and \or websites for accessibility, the topic is becoming increasingly complex with Smith and Stahl (2016) developing a UDL Scan Tool that moves beyond reliance on physical accessibility to test for compliance to Universal Design principles.

Middling findings regarding links or references to the Web and or accessibility standards would seem to echo Green and Huprich's (2009) findings of low percentages of materials passing accessibility evaluation. While a significant number of institutions provide information on accessibility standards, approximately $90 \%$ of those only refer to web accessibility and do not address other related issues, such as guidelines

MCGOWAN / DOI: 10.5929/2019.1.14.2 
for print content, an issue noted by Axelrod (2018). With only $28.3 \%$ of studied institutions referencing or providing field standards that inform their implementation, institutions have yet to align with Yang and Chen's (2015) guidance of tracking the latest iteration of standards, which indicates that even institutions that intend to be compliant could fall behind due to a failure to implement new recommendations in a timely manner. In addition, given that there are no accessibility guidelines for content in printed form (Axelrod, 2017), it is not surprising the standard provision is low. On the other hand, the relatively high findings of terminology definitions may reflect an attempt to address issues, such as those found by McGuire (2014) of significant confusion regarding terminology in the accessible instruction field. In addition, relatively high findings of guidance materials seem to concur with Dabrowski, Basinska, and Sikorski's (2014) findings that user guidance was one of the four website attributes that positively relates to website satisfaction, or, to extend the thinking, support of the organization sponsoring the provision of information. A low performing finding of this study was the provision of resources targeted to parents or families - a disappointing finding, given Cai and Richdale's (2015) finding of a high number of unplanned transitions from secondary school settings amongst students with Autism Spectrum Disorder.

This study's finding regarding several entities involved in the sponsorship of accessible instructional materials seems to echo field literature noting responsibility confusion among stakeholders in postsecondary accessibility initiatives (Linder, 2015). Low findings regarding robust findings of implementation plans for accessible materials seems to reinforce Linder's recommendations for the need for institutional investment, including staffing and resources. Disappointedly low findings were found for institutional certification of course accessibility or accessibility badging efforts - a recommendation gaining traction to indicate institutional commitment to demonstrating compliance and awarding compliant activity (Gay, Djafarova, \& Zefi, 2017).

\section{Future Research Directions and Conclusions}

The literature review for this study identified significant gaps in supporting research and field literature, particularly regarding policy development and support of accessibility initiatives. There may be a fundamental flaw in accessibility research, particularly accessibility testing of platforms, materials, and technology, due to population sampling that includes large percentages of able-bodied individuals (perhaps due to convenience factors). In addition, this study found a lack of research implementing largescale structures of accessibility, such as a system, Regents, or statewide structure in higher education. However, accessibility awareness may be expanding to include field depth with several areas celebrating successes (Azzopardi et al., 2014; Izzo \& Bauer, 2015; Ladner, 2016) and self-identifying with the need to better address accessibility (Clouder et al., 2016; Neutens, 2015).

While few recommendations of a 2011 federal report have been implemented (Advisory Commission on Accessible Instructional Materials, 2011), educational accessibility has made progress from other field initiatives, such as the creation of a federal Center on Technology and Disability (https://www.ctdinstitute.org). An innovative W3C-WAl: New Horizons for 2020 panel and field organizational partners developed toolkits and resources for educational leaders to support instructional material development (Crossland et al., 2016). Stated commitments by higher education stakeholders include: publishers (Sage Publishing, n.d.; Macmillan Learning, n.d.; Wiley, n.d.), open material suppliers (OpenStax, n.d.), journals (ScienceDirect, n.d.; Oxford Academic, n.d.; JAMA Network, n.d.), e-book distributors (VitalSource, n.d.), and learning environments (Blackboard, n.d.; Canvas Document Team, 2015; Moodle, 2018). Complying with accessibility standards offers hope that the issue is penetrating to the depth and breadth of industry stakeholders. This study was inspired by the researcher's service on a state council invested in accessibility interests and with a mission to develop statewide policies, resources,

MCGOWAN / DOI: 10.5929/2019.1.14.2 
and practices to efficiently inform public higher education. Hopefully, this research will inform development and practices in similar groups, as well as higher education stakeholders to reject "separate but equal" forms of accommodation and change initiated by legal actions in favor of a more organic model that embraces Universal Design from the outset of course, program, and unit development and faculty professional development initiatives.

\section{References}

Advisory Commission on Accessible Instructional Materials (AIM) in Postsecondary Education for Students with Disabilities. (2011). Report of the Advisory Commission on Accessible Instructional Materials in Postsecondary Education for Students with Disabilities, 42(1). Retrieved from https://www2.ed.gov/about/bdscomm/list/aim/meeting/aim-report.pdf

Acosta-Vargas, P., Acosta, T., \& Luján-Mora, S. (2018). Challenges to assess accessibility in higher education websites: A comparative study of Latin America Universities (dataset). Repositorio Institucional de la Universidad de Alicante. Retrieved from http://hdl.handle.net/10045/74109

Adams, S. J., Halaychik, C., \& Mezick, J. (2018). Accessibility compliance: One state, two approaches. The Serials Librarian, 1-7. doi:/10.1080/0361526X.2018.1427963

Akhtar, S., Warburton, S., \& Xu, W. (2017). The use of an online learning and teaching system for monitoring computer aided design student participation and predicting student success. International Journal of Technology and Design Education, 27(2), 251-270. doi:10.1007/s10798015-9346-8

Akram, M., \& Sulaiman, R. B. (2017). A systematic literature review to determine the web accessibility issues in Saudi Arabian university and government websites for disabled people. International Journal of Advanced Computer Science and Applications, 8(6). doi: 10.14569/IJACSA.2017.080642

Alahmadi, T., \& Drew, S. (2016). An evaluation of the accessibility of top-ranking university websites: Accessibility rates from 2005 to 2015. In DEANZ Biennial Conference. (pp. 224-233). Hamiliton, New Zealand. Retrieved from http://www.academia.edu/30866048/An evaluation of the accessibility of topranking university websites Accessibility rates from 2005 to 2015

Axelrod, J. (2018, January). Making materials accessible to students in higher education institutes: Institutional obligations, methods of compliance, and recommendations for future action. Learned Publishing, 31(1), 39-44. doi: 10.1002/leap.1148

Azadbakht, E., Blair, J., \& Jones, L. (2017). Everyone's invited: A website usability study involving multiple library stakeholders. Information Technology \& Libraries, 36(4), 34-45. doi:10.6017/ital.v36i4.9959

Azzopardi, T., Johnson, A., Phillips, K., Dickson, C., Hengstberger-Sims, C., Goldsmith, M., \& Allan, T. (2014). Simulation as a learning strategy: Supporting undergraduate nursing students with disabilities. Journal of Clinical Nursing, 23(3-4), 402-409.

Basham, J., Lowrey, K., \& deNoyelles, A. (2010). Computer mediated communication in the Universal Design for Learning framework for preparation of special education teachers. Journal of Special Education Technology, 25(2), 31-44.

MCGOWAN / DOI: 10.5929/2019.1.14.2 
Black, R. D., Weinberg, L. A., \& Brodwin, M. G. (2015). Universal design for learning and instruction: Perspectives of students with disabilities in higher education. International, 25(2), 1-16. Retrieved from ERIC database: EJ1065166

Blackboard. (n.d.). Accessibility at Blackboard. Retrieved from http://www.blackboard.com/accessibility.html

Blummer, B., \& Kenton, J. M. (2017). Access and accessibility of academic libraries' electronic resources and services. Library Science and Administration: Concepts, Methodologies, Tools, and Applications: Concepts, Methodologies, Tools, and Applications, 188.

Brand, B., Valent, A., \& Danielson, L. (2013). Improving college and career readiness for students with disabilities. College \& Career Readiness \& Success Center, American Institutes for Research. Retrieved from ERIC database: ED555694

Brown, M., Dehoney, J., \& Millichap, N. (2015, April). The next generation digital learning environment. A Report on Research. ELI Paper. Louisville, CO: Educause.

Cai, R., \& Richdale, A. (2016). Educational experiences and needs of higher education students with autism spectrum disorder. Journal of Autism and Developmental Disorders, 46(1), 31-41. doi:10.1007/s10803-015-2535-1

Canvas Document Team (2015, April 7). Accessibility within Canvas. Retrieved from https://community.canvasIms.com/docs/DOC-2061-accessibility-within-canvas

Carey, T. (2015). Create a process for video captioning that ensures access for deaf, hard-of-hearing students. Disability Compliance for Higher Education, 21(4), 7. doi:10.1002/dhe

Chen, W., Sanderson, N. C., Kessel, S., \& Królak, A. (2015). Heuristic evaluations of the accessibility of learning management systems (LMSs) as authoring tools for teachers. First Monday, 20(9). doi: 10.5210/fm.v20i9.5430

Chern, A., Lai, Y., Chang, Y., Tsao, Y., Chang, R., \& Chang, H. (2017). A smartphone-based multifunctional hearing assistive system to facilitate speech recognition in the classroom. IEEE Access, 5. doi:10.1109/ACCESS.2017.2711489

Cifuentes, L., Janney, A., Guerra, L., \& Weir, J. (2016). A working model for complying with accessibility guidelines for online learning. Techtrends: Linking Research and Practice to Improve Learning Publication of the Association for Educational Communications \& Technology, 60(6), 557-564. doi:10.1007/s11528-016-0086-8

Clouder, L., Adefila, A., Jackson, C., Opie, J., \& Odedra, S. (2016). The discourse of disability in higher education: Insights from a health and social care perspective. International Journal of Educational Research, 79, 10-20.

Conrad, L. Y., \& Kasdorf, B. (2018). Making accessibility more accurate to publishers. The Association of Learned \& Professional Society Publishers. doi:10.1002/leap.1154

Cortiella, C., \& Horowitz, S. H. (2014). The state of learning disabilities: Facts, trends and emerging issues. New York, NY: National Center for Learning Disabilities. Retrieved from https://www.ncld.org/wp-content/uploads/2014/11/2014-State-of-LD.pdf

Crossland, A., Gray, T., Reynolds, J., Wellington, D., \& Zhou, A. (2016, October). Digital Accessibility Toolkit: What education leaders need to know. Center on Technology and Disability. Retrieved

MCGOWAN / DOI: 10.5929/2019.1.14.2 
from http://www.ctdinstitute.org/sites/default/files/file attachments/AccessibilityToolkit508 FINAL 100616.pdf

Dabrowski, D., Basinska, B. A., \& Sikorski, M. (2014). Impact of usability website attributes on users' trust, satisfaction and loyalty. Social Sciences, 85(3), 22-32. doi:10.5755/j01.ss.85.3.8409

DeLancey, Laura. (2015). Assessing the accuracy of vendor-supplied accessibility documentation. Library Hi Tech, 33 (1), 103-113. doi:10.1108/LHT-08-2014-0077

Dong, S., \& Lucas, M. S. (2016). An analysis of disability, academic performance, and seeking support in one university setting. Career Development and Transition for Exceptional Individuals, 39(1), 4756. doi:10.1177/2165143413475658

Dunnam, J. (2016). Understanding and reducing inaccuracy in electronically generated braille. Journal of Blindness Innovation and Research, 6(3). doi: 10.5241/6-ICEB-10

Flaherty, M., \& Roussy, A. (2014). A failed game changer: Post-secondary education and the accessibility for Ontarians with Disabilities Act. Education \& Law Journal, 24(1), 1-23. Retrieved from https://ssrn.com/abstract=2510991

Gallego, M., \& Busch, C. (2015). Towards the inclusion of students with disabilities: Accessibility in language courses. Innovative Higher Education, 40(5), 387-398. doi:10.1007/s10755-015-9321-z

Gay, G., Djafarova, N., \& Zefi, L. (2017). Teaching accessibility to the masses. Proceedings of the 14th Web for All Conference on the Future of Accessible Work, 15. ACM Digital Library. doi: $10.1145 / 3058555.3058563$

George, S., Clement, E., Hudson, G., \& Asif, M. (2014). Auditing the accessibility of electronic resources. In I. Hall, S. Thornton, \& S. Town (Eds.). Proceedings of the 10th Northumbria International Conference on Performance Measurement in Libraries and Information Services (pp. 95-104). University of York.

Gladhart, M. A. (2010). Determining faculty needs for delivering accessible electronically delivered instruction in higher education. Journal of Postsecondary Education and Disability, 22(3), 185-196.

Grana, R. A., \& Ling, P. M. (2014). "Smoking revolution": A content analysis of electronic cigarette retail websites. American Journal of Preventive Medicine, 46(4), 395-403. doi: 10.1016/j.amepre.2013.12.010

Green, R. A., \& Huprich, J. (2009). Web accessibility and accessibility instruction. Journal of Access Services, 6(1-2), 116-136. doi:10.1080/15367960802247825

Izzo, M. V., \& Bauer, W. M. (2015, March). Universal design for learning: Enhancing achievement and employment of STEM students with disabilities. Universal Access in the Information Society, 14, 17. doi: 10.1007/s10209-013-0332-1

JAMA Network. (n.d.). Accessibility statement. Retrieved from https://jamanetwork.com/pages/accessibility-statement

Kaufmann, K. F., Perez, G., \& Bryant, M. (2018). Reaching shared goals in higher education: A collaboration of the library and disability support services. Library Leadership \& Management, 32(2). Retrieved from https://journals.tdl.org/llm/index.php/IIm/article/view/7194

MCGOWAN / DOI: 10.5929/2019.1.14.2 
Kent, M. (2015). Disability and eLearning: Opportunities and barriers. Disability Studies Quarterly, 35(1).

King, J. (2014). Retention of Undergraduate Students with Disabilities at the University of Washington. Dissertation from University of Washington. Retrieved from https://digital.lib.washington.edu/researchworks/bitstream/handle/1773/26289/King washingt on $0250 \mathrm{E}$ 13470.pdf?sequence $=1$

Knight, W., Wessel, R. D., \& Markle, L. (2018). Persistence to graduation for students with disabilities: Implications for performance-based outcomes. Journal of College Student Retention: Research, Theory \& Practice, 19(4), 362-380. doi: 10.1177/1521025116632534

Ladner, R. E. (2016, October). Accessibility is Becoming Mainstream. In Proceedings of the 18th International ACM SIGACCESS Conference on Computers and Accessibility (pp. 1-1). ACM.

Larkin, H., Dell, K., \& Hitch, D. (2016). Students' attitudes to universal design in architecture education. Journal of Social Inclusion, 7(2), 18-34. Retrieved from http://universaldesignaustralia.net.au/wpcontent/uploads/2016/12/Helen-Larkin-student-attitudes.pdf

Levey, J. A. (2018, May\June). Universal design for instruction in nursing education: An integrative review. Nursing Education Perspectives 39(3), 156-161. doi: 10.1097/01.NEP.0000000000000249

Linder, K. E., Fontaine-Rainen, D. L., \& Behling, K. (2015). Whose job is it? Key challenges and future directions for online accessibility in US institutions of higher education. Open Learning: The Journal of Open, Distance, and e-Learning, 30(1). doi: 10.1080/02680513.2015.1007859

Lombard, M., Snyder-Duch, J., \& Bracken, C. C. (2002). Content analysis in mass communication: Assessment and reporting of intercoder reliability. Human communication research, 28(4), 587604.

Lombardi, A., \& Murray, C. (2011). Measuring university faculty attitudes toward disability: Willingness to accommodate and adopt universal design principles. Journal of Vocational Rehabilitation, 34(1), 43-56.

$\begin{array}{lllll}\text { Macmillan } & \text { (n.d.). } & \text { Accessibility. } & \text { Retrieved from }\end{array}$ https://macmillanlearning.com/catalog/page/accessibility

Margolin, J., Shazia, R. M., \& Rosenbaum, J. E. (2013). The community college website as virtual advisor: A usability study. Community College Review, 41(1). doi: 10.1177/0091552112471844

Massengale, L. R., \& Vasquez, E. (2016). Assessing accessibility: Are online courses better than face-toface instruction at providing access to course content for students with disabilities? Journal of the Scholarship of Teaching and Learning, 16(1), 69-79.

Mayes, A. (2018). Captioning and subtitling benefit all students for increased literacy. Minnesota Commission on the Blind, Deaf, \& Hard of Hearing. Retrieved from https://mn.gov/deafcommission/news/?id=1063-335385

McClellan, M. A., Karumur, R. P., Vogel, R. I., Petzel, S. V., Cragg, J., Chan, D., ... Geller, M. A. (2016). Designing an educational website to improve quality of supportive oncology care for women with ovarian cancer: An expert usability review and analysis. International Journal of Human-Computer Interaction, 32(4), 297-307. doi:10.1080/10447318.2016.1140528

McGuire, J. M. (2014, Winter). Universally accessible instruction: Oxymoron or opportunity? Journal of Postsecondary Education \& Disability, 27(4), 387. Retrieved from ERIC database: EJ1060009

MCGOWAN / DOI: 10.5929/2019.1.14.2 
Mishra, M., Pattanaik, B., \& Mahapatra, R. K. (2017). Accountability and accessibility of library resources in print media of Odisha: A study. Pearl: A Journal of Library and Information Science, 11(3), 279286.

Moodle. (2018, March 16). Accessibility. Retrieved from https://docs.moodle.org/dev/Accessibility

Moore, E. J., Smith, F. G., Hollingshead, A., \& Wojcik, B. (2017). Voices from the field: Implementing and scaling-up Universal Design for learning in teacher preparation programs. Journal of Special Education Technology, 33(1), 40-53. doi:10.1177/0162643417732293

National Center on Accessible Educational Materials. (2004). National Instructional Materials Accessibility Standard (NIMSA) v 1.1. Retrieved from aem.cast.org

Neuendorf, K. A. (2016). The content analysis guidebook. Sage.

Neutens, T. (2015). Accessibility, equity and health care: Review and research directions for transport geographers. Journal of Transport Geography, 43, 14-27.

Newman, L., Wagner, M., Knokey, A., Marder, C., Nagle, K., Shaver, D., ... Schwarting, M. (2011). The post-high school outcomes of young adults with disabilities up to 8 years after high school: A report from the National Longitudinal Transition Study-2 (NLTS2) (NCSER 2011-3005). Menlo Park, CA: SRI International.

Noble, H. (2010). Improving the experience of deaf students in higher education. British Journal of Nursing, 19(13), 851-854. doi: 10.12968/bjon.2010.19.13.48863

O'Connor, K. (2014). MOOCs, institutional policy and change dynamics in higher education. Higher Education, 68(5), 623-635. doi:10.1007/s10734-014-9735-z

Office of Civil Rights. (n.d.). Developing effective grievance procedures. Retrieved from https://www2.ed.gov/about/offices/list/ocr/grievance.html

Oku, H., Matsubara, K., \& Booka, M. (2015). Usability of PDF-based digital textbooks to the physically disabled university student. Studies in Health Technology and Informatics, 2173-10. doi: 10.3233/978-1-61499-566-1-3

OpenStax. (n.d). Accessibility. Retrieved from https://openstax.org/accessibility-statement

Oxford Academic. (n.d.). Accessibility statement. Retrieved from https://academic.oup.com/journals/pages/about us/legal/accessibility

Phukubje, J., \& Ngoepe, M. (2017). Convenience and accessibility of library services to students with disabilities at the University of Limpopo in South Africa. Journal of Librarianship and Information Science, 49(2), 180-190. doi: 10.1177/0961000616654959

Pirani, Z., \& Sasikumar, M. (2014). Accessibility issues in learning management systems for learning disabled: A survey. In Recent Advances in Intelligent Informatics (pp. 253-264). Springer, Cham.

Rains, S., \& Bosch, L. (2009). Privacy and health in the information age: A content analysis of health web site privacy policy statements. Health Communication, 24(5), 435-446. doi: $10.1080 / 10410230903023485$

Ringlaben, R., Bray, M., \& Packard, A. (2014). Accessibility of American university special education departments' web sites. Universal Access in the Information Society, 13(2), 249-254.

MCGOWAN / DOI: 10.5929/2019.1.14.2 
Rosen, S. (2018). What does a library accessibility specialist do? How a new role advances accessibility through education and advocacy. College \& Research Libraries News, 79(1), 23. Retrieved from https://crln.acrl.org/index.php/crlnews/article/view/16861/18483

SAGE Publishing. (n.d.). Accessibility. Retrieved from https://us.sagepub.com/en-us/nam/accessibility

$\begin{array}{lllll}\text { ScienceDirect. } & \text { (n.d.). Web accessibility. } & \text { Retrieved from }\end{array}$ https://www.elsevier.com/solutions/sciencedirect/support/web-accessibility

Seale, J., Georgeson, J., Mamas, C., \& Swain, J. (2015). Not the right kind of 'digital capital'? An examination of the complex relationship between disabled students, their technologies and higher education institutions. Computers \& Education, 82,118-128

Shinohara, K., Kawas, S., Ko, A. J., \& Ladner, R. E. (2018, February). Who teaches accessibility?: A survey of US computing faculty. In Proceedings of the 49th ACM Technical Symposium on Computer Science Education. (pp. 197-202). ACM.

Slater, R., Pearson, V. K., Warren, J. P., \& Forbes, T. (2015). Institutional change for improving accessibility in the design and delivery of distance learning-the role of faculty accessibility specialists at The Open University. Open Learning: The Journal of Open, Distance, and e-Learning, 30(1). doi: 10.1080/02680513.2015.1013528

Small, R. V., Myhill, W. N., \& Herring-Harrington, L. (2015). Developing accessible libraries and inclusive librarians in the 21st century: Examples from practice. In B. Wentz, P. T. Jaeger, J. C. Bertot (Eds.), Accessibility for Persons with Disabilities and the Inclusive Future of Libraries (Advances in Librarianship, Volume 40) (pp. 73-88). Emerald Group Publishing Limited.

Smith, S., \& Stahl, W. (2016). Determining the accessibility of k-12 digital materials: Tools for educators. Journal of Special Education Leadership, 29(2), 89-100. Retrieved from ERIC database: EJ1118558

State Educational Technology Directors Association. (2018). Digital instructional materials acquisition polices for States: State comparison. Retrieved from http://dmaps.setda.org/

Thompson, T., Comden, D., Ferguson, S., Burgstahler, S., \& Moore, E. J. (2013, April). Seeking predictors of web accessibility in U.S. higher education institutions. Information Technology and Disabilities Journal, 8(1). Retrieved from http://itd.athenpro.org/volume13/number1/thompson.html

Tyler, M., Jones, C., Grebennikov, L., Leigh, G., Noble, W., \& Burnham, D. (2009). Effect of caption rate on the comprehension of educational television programmes by deaf school students. Deafness \& Education International, 11(3), 152-162. doi:10.1002/dei.262

VitalSource. (n.d.). Accessibility. Retrieved from https://support.vitalsource.com/hc/enus/categories/200184597-Accessibility

Vitelli, E. (2015). Universal design for learning: Are we teaching it to preservice general education teachers? Journal of Special Education Technology, 30(3), 166-178. doi:10.1177/0162643415618931

Wei, H. C., Peng, H., \& Chou, C. (2015). Can more interactivity improve learning achievement in an online course? Effects of college students' perception and actual use of a course-management system on their learning achievement. Computers \& Education, 83, 10-21.

Wei, X., Yu, J., Shattuck, P., McCracken, M., \& Blackorby, J. (2013). Science, technology, engineering, and mathematics (STEM) participation among college students with an autism spectrum disorder.

MCGOWAN / DOI: 10.5929/2019.1.14.2 
Journal of Autism and Developmental Disorders, 43(7), 1539-1546. doi:10.1007/s10803-012$1700-z$

Wiley. (n.d.). Accessibility. Retrieved from https://www.wiley.com/en-us/accessibility

Yang, Y. T., \& Chen, B. (2015, October). Web accessibility for older adults: A comparative analysis of disability laws. The Gerontologist, 55(5), 854-864. doi:10.1093/geront/gnv057

Zekveld, A., Kramer, S., Kessens, J., Vlaming, M., \& Houtgast, T. (2009). User evaluation of a communication system that automatically generates captions to improve telephone communication. Trends in Amplification, 13(1), 44-68.

\section{About the Author}

Veronica McGowan (veronica.mcgowan@swosu.edu) serves as the Activity Director of the Student Success Center at Southwestern Oklahoma State University. Dr. McGowan currently serves as co-chair of the Open Educational Resources subgroup for the Oklahoma State Regents of Higher Education's Council of Online Learning. She is the Vice President of the Board of Education at the Insight School of Oklahoma, a public virtual charter school for grades 7-12 in Midwest City, Oklahoma and currently serves as an Assessment Academy Mentor with the Higher Learning Commission (HLC) and as an Evaluation Reviewer and Assessment Expert for the Accreditation Council for Business Schools and Programs (ACBSP). 